\title{
Minor neuropsychological deficits in patients with subjective cognitive decline
}

Steffen Wolfsgruber, PhD ${ }^{a, b,}$, , Luca Kleineidam, M.Sc. ${ }^{\text {a,b, }}$, Jannis Guski, B.Sc. ${ }^{a, b}$, Alexandra Polcher M.Sc. ${ }^{a, b}$, Ingo Frommann, Dipl.-Psych. ${ }^{a, b}$, Sandra Roeske, $P h D^{a}$, Eike Jakob Spruth, $M D^{c, d}$, Christiana Franke, $M^{d}$, Josef Priller, MD ${ }^{c, d}$, Ingo Kilimann, MD ${ }^{e, f}$, Stefan Teipel, MD ${ }^{e, f}$, Katharina Buerger, $M D^{g, h}$, Daniel Janowitz ${ }^{h}$, Theresa Stapf, $M D^{h}$, Christoph Laske, MD ${ }^{i, j}$, Martina Buchmann, MD ${ }^{\mathrm{i}, \mathrm{j}}$, Oliver Peters, MD ${ }^{\mathrm{c}, \mathrm{k}}$, Felix Menne, Dipl.-Psych. ${ }^{\mathrm{c}, \mathrm{k}}$, Manuel Fuentes Casan, Dipl.-Psych., ${ }^{c, k}$, Jens Wiltfang, MD ${ }^{1, m}$, Claudia Bartels, PhD ${ }^{1, m}$, Emrah Düzel, MD ${ }^{\mathrm{n}, \mathrm{o}}$, Coraline Metzger, $\mathrm{MD}^{\mathrm{n}, \mathrm{o}, \mathrm{p}}$, Wenzel Glanz, $\mathrm{MD}^{\circ}$, Manuela Thelen, Dipl.-Biol. ${ }^{\mathrm{a}, \mathrm{s}}$, Annika Spottke, MD ${ }^{\mathrm{a}, \mathrm{q}}$, Alfredo Ramirez, MD ${ }^{\mathrm{a}, \mathrm{b}, \mathrm{r}}$, Barbara Kofler, MD ${ }^{a, b}$, Klaus Fließbach, MD ${ }^{a, b}$, Anja Schneider, MD ${ }^{a, b}$, Michael Heneka, MD ${ }^{a, b}$, Frederic Brosseron, PhD ${ }^{a, b}$, Dix Meiberth, M.Sc. ${ }^{\text {a,s }}$, Frank Jessen, $M D^{a, s}$ and Michael Wagner, $P h D^{a, b}$, On behalf of the DELCODE study group.

* These authors contributed equally to this manuscript.

${ }^{a}$ German Center for Neurodegenerative Diseases (DZNE), Bonn, Germany

${ }^{b}$ Department of Neurodegenerative Diseases and Geriatric Psychiatry, University of Bonn, Germany

${ }^{c}$ German Center for Neurodegenerative Diseases (DZNE), Berlin, Germany

${ }^{d}$ Department of Psychiatry and Psychotherapy, Charité - Universitätsmedizin Berlin, Germany

${ }^{e}$ German Center for Neurodegenerative Diseases (DZNE), Rostock, Germany

${ }^{f}$ Department of Psychosomatic Medicine, Rostock University Medical Center, Rostock, Germany,

${ }^{9}$ German Center for Neurodegenerative Diseases (DZNE) Munich, Germany

${ }^{\mathrm{h}}$ Institute for Stroke and Dementia Research, University Hospital, LMU Munich, Munich, Germany 
'German Center for Neurodegenerative Diseases (DZNE), Tübingen, Germany

j Section for Dementia Research, Hertie Institute for Clinical Brain Research and Department of Psychiatry and Psychotherapy, University of Tübingen, Germany

${ }^{k}$ Charité - Universitätsmedizin Berlin, corporate member of Freie Universität Berlin, Humboldt-Universität zu Berlin, and Berlin Institute of Health, Institute of Psychiatry and Psychotherapy, Berlin, Germany

' German Center for Neurodegenerative Diseases (DZNE), Goettingen, Germany

m Department of Psychiatry and Psychotherapy, University Medical Center Goettingen, University of Goettingen, Germany

${ }^{\mathrm{n}}$ German Center for Neurodegenerative Diseases (DZNE), Magdeburg, Germany

${ }^{\circ}$ Institute of Cognitive Neurology and Dementia Research (IKND), Otto-vonGuericke University, Magdeburg, Germany

${ }^{\mathrm{P}}$ Department of Psychiatry and Psychotherapy, Otto-von-Guericke University, Magdeburg, Germany

${ }^{q}$ Department of Neurology, University Hospital Bonn, Germany

${ }^{r}$ Division of Neurogenetics and Molecular Psychiatry, Department of Psychiatry, Medical Faculty University of Cologne, Germany

${ }^{\mathrm{s}}$ Department of Psychiatry, Medical Faculty University of Cologne, Germany

Search Terms: [26] Alzheimer's disease; [38] Assessment of cognitive disorders/dementia; [201] Memory; [205] Neuropsychological assessment; [additional] Subjective Cognitive Decline.

Submission Type: Article

Title Character count: $\mathbf{8 0}$ 
Word count of Abstract: 225

Word count of paper: 4267

Number of references: $\mathbf{4 2}$

Number of Tables: $\mathbf{3}$

Number of Figures: 1

Supplementary data: $\mathbf{1}$ appendix and $\mathbf{1}$ figure

\section{Corresponding author:}

Dr. Phil. Steffen Wolfsgruber, Dipl.-Psych.

German Center for Neurodegenerative Diseases, Bonn, Sigmund-Freud-

Straße 27, D-53127, Bonn, Germany

Phone: +49-228-43302-816;

Email: Steffen.Wolfsgruber@dzne.de

Financial Disclosures: Authors Wolfsgruber, Kleineidam, Guski, Polcher, Frommann, Roeske, Spruth, Franke, Kilimann, Teipel, Buerger, Janowitz ${ }^{\text {h }}$ Stapf, Laske, Buchmann, Peters, Menne, Fuentes Casan, Wiltfang, Bartels, Düzel, Metzger, Glanz, Thelen, Spottke, Ramirez, Kofler, Fließbach, Schneider, Heneka, Brosseron, Meiberth, and Wagner report no disclosures.

Dr. Jessen received fees for consultation from Eli Lilly, Novartis, Roche, BioGene, MSD, Piramal, Janssen, Lundbeck

Dr. Priller received fees for consultation, lectures, patents from: Neurimmune, Axon, Desitin, Epomedics

Statistical analysis conducted by Dr. Steffen Wolfsgruber, PhD, Luca Kleineidam, M.Sc., Jannis Guski, B.Sc., all from German Center for Neurodegenerative Diseases, Bonn, Germany 
Wolfsgruber et al. 4

Study Funded by the German Center for Neurodegenerative Diseases

(Deutsches Zentrum für Neurodegenerative Erkrankungen, DZNE), reference number BN012. The funders had no role in study design, data collection and analysis, decision to publish, or preparation of the manuscript. 
Wolfsgruber et al. 5

\section{Abstract}

2 Objective: To determine the nature and extent of minor neuropsychological

3 deficits in patients with subjective cognitive decline (SCD) and their

4 association with cerebrospinal fluid (CSF) biomarkers of Alzheimer's disease

5 (AD).

6 Method: We analyzed data from $n=449$ cognitively normal participants

7 ( $n=209$ healthy controls, $n=240$ SCD patients) from an interim data release of

8 the German Center for Neurodegenerative Diseases Longitudinal Cognitive

9 Impairment and Dementia Study (DELCODE). An extensive

10 neuropsychological test battery was applied at baseline for which we

11 established a latent, five cognitive domain factor structure comprising learning

12 \& memory, executive functions, language abilities, working memory and

13 visuospatial functions. We compared groups regarding global and domain-

14 specific performance and correlated performance with different CSF markers

15 of $A D$ pathology.

16 Results: We observed worse performance (Cohen's $d \approx 0.25-0.5$, adjusted for

17 age-, sex differences with ANCOVA) in global performance, memory,

18 executive functions and language abilities for the SCD group compared to

19 healthy controls. In addition, worse performance in these domains was

20 moderately $(r \approx 0.3)$ associated with lower CSF-Aß42/40 and CSF-

$21 \mathrm{~A} \beta 42 /$ ptau181 in the whole sample and specifically in the SCD subgroup.

22 Conclusions: Within the spectrum of clinically unimpaired (i.e., "pre- mild

23 cognitive impairment") cognitive performance, SCD is associated with minor

24 deficits in memory, executive function and language abilities. The association 
Wolfsgruber et al. 6

1 of these subtle cognitive deficits with AD CSF biomarkers speaks to their

2 validity and potential use for the early detection of underlying preclinical AD. 


\section{Introduction}

2 Individuals with subjective cognitive decline (SCD) subjectively experience a

3 decline in cognitive functioning while still performing within the age-, sex- and

4 education-adjusted normal limits on standard cognitive tests ${ }^{1,2}$. Due to their

5 preserved cognition, help-seeking behavior and increased risk for future

6 Alzheimer's disease (AD) dementia ${ }^{3}$, individuals with SCD, especially within

7 the memory clinic setting ${ }^{4}$, are highly relevant for the concept of early

8 intervention. Recent research has largely focused on identifying the

9 quantitative and qualitative aspects of SCD specifically related to underlying

$10 \mathrm{AD}$ pathology ${ }^{5}$. In contrast, a deeper characterization of neuropsychological

11 performance in this group has been somewhat neglected. Objective

12 neuropsychological information in SCD is primarily used to demark it from the

13 mild cognitive impairment $(\mathrm{MCl})$ stage. This may have implicitly suggested

14 that variance in neuropsychological performance may not have further

15 relevance for the prediction of underlying $A D$ pathology and the risk of clinical

16 progression in "cognitively unimpaired" SCD patients. Thus, it currently

17 remains unclear (1) whether memory clinic patients with SCD still exhibit

18 minor cognitive deficits compared to cognitively normal individuals without

$19 S C D,(2)$ whether these patients manifest deficiencies in specific domains of

20 cognition, and (3) whether these deficiencies are associated with the self-

21 /informant reported extent of SCD as well as biomarkers of AD pathology. In

22 the present study, we therefore compared neuropsychological performance in

23 five different cognitive domains between memory clinic patients with SCD and

24 healthy controls and associated it with the extent of self-/informant rated SCD

25 and CSF biomarkers of AD pathology. 
Wolfsgruber et al. 8

\section{Methods}

2 Standard Protocol Approvals, Registrations, and Patient Consent

3 The study protocol was approved by local institutional review boards and

4 ethical committees of all participating sites of the German Center for

5 Neurodegenerative Diseases (DZNE) Longitudinal Cognitive Impairment and

6 Dementia Study (DELCODE). All participants in the study provided written

7 informed consent.

8 DELCODE study

9 DELCODE is an observational longitudinal multicenter study carried out by

10 ten university-based memory clinics collaborating with local sites of the DZNE

$1{ }^{6}$. All patients of DELCODE are referrals, including self-referrals, to the

12 participating memory centers, while two nonpatient groups were recruited by

13 standardized public advertisement (see below). All participants were required

14 to be age $\geq 60$ years. Further requirements were fluent German language

15 skills, capacity to provide informed consent, and presence of a study partner.

16 Recruitment started in 2015 and, at time of data extraction for the present

17 study (Oct 2018), was still ongoing.

18 DELCODE has a focus on cognitively normal memory clinic patients with SCD

19 and includes a comparison group of healthy controls $(\mathrm{HC})$ without subjective

20 or objective impairment. The study also recruited cognitively normal first-

21 degree relatives of patients with $A D$ dementia (hereafter named "AD

22 relatives") as an exploratory at risk group. However, we did not include them

23 in the present report due to a yet to small sample size. In addition, the study

24 also included amnestic $\mathrm{MCl}$ and mild $\mathrm{AD}$ dementia patients. A detailed 
1 description of the complete study protocol, including all general

2 inclusion/exclusion criteria as well as diagnostic criteria of all groups, has

3 been published recently ${ }^{6}$. Here, we included $n=209 \mathrm{HC}$ and $n=242 \mathrm{SCD}$

4 patients selected from an interim data release. In addition, this data release

5 sample included $\mathrm{n}=115$ amnestic $\mathrm{MCl}$ patients, $\mathrm{n}=77$ mild $\mathrm{AD}$ dementia

6 patients and $n=44 A D$ relatives. We used the latter three groups only in the

7 model estimation to derive the cognitive domain scores (see below and

8 appendix e-1).

9 Definition of cognitively normal participant groups

10 In line with current research criteria ${ }^{1,2}$, the SCD patient group was defined by

11 the presence of subjectively self-reported decline in cognitive functioning with

12 concerns as expressed to the physician of the respective memory center and

13 a test performance of better than -1.5 standard deviations (SD) below the

14 age, sex, and education-adjusted normal performance on all subtests of the

15 Consortium to Establish a Registry for Alzheimer's Disease (CERAD)

16 neuropsychological battery. We applied the CERAD battery as part of the

17 clinical routine at each site. This provided the neuropsychological information

18 for the entry diagnosis in DELCODE (i.e., this assessment was not part of the

19 DELCODE baseline visit itself).

20 We recruited the $\mathrm{HC}$ group by local newspaper advertisement explicitly asking

21 for individuals who felt healthy and without relevant cognitive problems. We

22 screened all individuals who responded to the advertisement by telephone

23 with regard to the presence of SCD. The report of very subtle cognitive

24 decline experienced as normal for the age of the individual and not causing

25 concerns was not an exclusion criterion for the $\mathrm{HC}$ group. 
1 The $\mathrm{HC}$ group had to achieve unimpaired cognitive performance according to

2 the same definition as the SCD group. Neuropsychological information to

3 verify adherence to this criterion for these participants stems from the

4 DELCODE baseline assessment because, unlike the SCD patient group,

5 these participants did not undergo the routine diagnostic work-up in the

6 memory clinic.

$7 \quad$ Assessments

8 Standardized assessment and diagnostic procedures of DELCODE have

9 been described previously ${ }^{6}$. Here, we focus on a description of the

10 assessments relevant to the present study, i.e., assessment and processing

11 of neuropsychological data and CSF biomarker data.

12 Neuropsychological assessment and derivation of cognitive domain scores via

13 confirmatory factor analysis

14 As part of the clinical assessment, we applied the DELCODE

15 neuropsychological assessment battery (hereafter called "DELCODE-NP") at

16 baseline. We selected the tests to serve the aims of (1) comparability with

17 similar ongoing studies addressing prodromal and preclinical AD (e.g., ADNI,

18 WRAP) ${ }^{7,8},(2)$ measuring different cognitive domains (see below) and (3)

19 including tests used in cognitive composite scores (e.g., the "Preclinical

20 Alzheimer cognitive composite" (PACC) ${ }^{9}$ ) for tracking cognitive decline.

21 The DELCODE-NP includes the Mini Mental State Examination (MMSE) ${ }^{10}$, 22 ADAS-Cog $13^{11}$, the Free and Cued Selective Reminding Test (FCSRT) ${ }^{12}$, 23 which includes a serial subtraction task, Wechsler Memory Scale revised 24 version (WMS-R) Logical Memory (Story A) and Digit Span ${ }^{13}$, two semantic 
1 fluency tasks (animals and groceries ${ }^{14}$ ), the Boston Naming Test (15 item

2 short version analogue to the CERAD battery ${ }^{15}$, supplemented by 5

3 infrequent items from the long version ${ }^{14}$ ), the oral form of the Symbol-Digit-

4 Modalities Test (including a subsequent free recall of symbols and symbol-

5 digit pairings ${ }^{16}$ ), Trail Making Test $A$ and $B{ }^{17}$, Clock Drawing and Clock

6 Copying ${ }^{18}$, and a recall task of previously copied figures (as in the CERAD

7 test battery ${ }^{15}$ ). In addition to these established tests, two newly developed

8 computerized tests were implemented: the Face Name Associative

9 Recognition Test ${ }^{19}$ and a Flanker task to assess executive control of attention

1020.

11 Of note, comparability between the DELCODE-NP and the CERAD test

12 battery is ensured by the fact that every CERAD test is included in the

13 DELCODE-NP, either by addition to the battery as a single test or (in the case

14 of word list learning and recall, object naming, and figure copying) by using

15 the equivalent of the ADAS-Cog 13 with minor adjustments of items and/or

16 scoring according to the CERAD version. Raw behavioral data were recorded

17 to allow scoring analogous to both the CERAD and ADAS-Cog 13

18 procedures. For the present study, we scored the tests according to CERAD

19 procedures ${ }^{11}$ to ensure applicability of the CERAD-based criteria for cognitive

20 normality (see above) in the HC group. We also developed parallel versions of

21 the word list learning task to counteract potential practice effects due to item

22 familiarity in the SCD patient group, as for these participants the baseline

23 assessment was the second time they were exposed to those tests of the

24 DELCODE-NP that were also part of the CERAD-based neuropsychological

25 examination during the screening visit. Importantly, all participant groups were 
1 tested with exactly the same test battery, including the same version of the

2 word list, at the baseline visit.

3 We then used confirmatory factor analysis (CFA) to derive five cognitive

4 domain scores: Learning \& memory (MEM), language ability (LANG),

5 executive functions and mental processing speed (EXEC), working memory

6 (WM) and visuo-spatial abilities (VIS). In addition, we derived a global

7 cognitive performance score as the average of the five domain scores.

8 Further details of the CFA procedures are given in appendix e-1 and figure-

9 e1. Two participants from the SCD group had to be excluded from the model

10 estimation due to missing data on all neuropsychological variables (reducing

11 the SCD sample of the present study to $n=240$ ).

12 Interview-based assessment of the extent of subjective cognitive decline

13 We assessed subjective reports of cognitive decline in different domains with

14 a structured clinical interview ("Subjective Cognitive Decline Interview; SCD-I;

$15^{21}$ ). The SCD-I allows assessment of SCD in five different cognitive domains

16 (memory, language, planning, attention, others). All interviews were

17 administered by trained study physicians and lasted approximately five

18 minutes. For each cognitive domain, the physician asked the patient if he/she

19 had noticed any worsening in function (e.g., "do you feel like your memory has

20 worsened?"). If the participant answered this question with yes, the physician

21 added more in-depth questions about the domain to assess the

22 presence/absence of SCD-plus features ${ }^{2}$, i.e., specific questions proposed to

23 increase the likelihood of underlying AD pathology if confirmed. These are,

24 e.g., questions about the presence of associated worries ("Does this worry

25 you?") or the onset ("How long ago did you start to notice the decline?"). In 
1 addition, the semistructured interview was administered to a study-partner

2 (relative) of the participant to obtain information on confirmation of the

3 participant's perceived decline in each cognitive domain. The quantification of

4 response data allows derivation of different sum scores, including the total

5 number of cognitive domains (memory, language, planning, attention, others)

6 in which the participant endorses a worsening in function (maximum score =

7 5). The same score can be derived for the informant report. We used these

8 two scores for our analyses.

9 CSF biomarker assessment

10 Procedures of CSF acquisition, processing and analysis in DELCODE have

11 been previously described ${ }^{6}$. In the present study, we focused on the CSF-

$12 \mathrm{~A} \beta 42 / \mathrm{A} \beta 40$ ratio as the arguably best CSF marker for amyloid pathology ${ }^{22}$. In

13 addition, we used the CSF-pTau181 level as a marker for aggregated tau

14 neurofibrillary tangles and the total CSF-Tau level as a marker for

15 neurodegeneration, according to the most recent NIA-AA guidelines' "AT(N)

16 system" ${ }^{23}$. We decided to use continuous biomarker values (rather than

17 categorical variables based on cutoffs) to explore the strength of the

18 association of cognitive performance with biomarkers within the complete

19 spectrum of preclinical AD pathological change, without loss of information

20 due to dichotomization. The latter would be required in a study of diagnostic

21 utility, which is not the focus of this study. In line with this, we used the ratio of

22 CSF-Aß42/p-Tau181 as a continuous, highly AD-specific biomarker ${ }^{24}$.

\section{Statistical analysis}


1 The following statistical analyses were conducted with IBM SPSS Statistics

2 for Windows, Version 22.0. Armonk, NY. As this is an exploratory rather than

3 a confirmatory analysis, we reported unadjusted p-values. We reported

4 descriptive statistics of the combined sample as well as differences between

5 the HC and SCD group based on ANOVA for continuous and Chi-square tests

6 for categorical variables. We further compared the two groups with regard to

7 their performance in the CFA-derived factor scores as the main dependent

8 variables of interest. We rescaled the factor score values using a z-

9 transformation with mean and standard deviation taken from the HC group.

10 For this group comparison, we employed a series of ANCOVAs with age and

11 sex as covariates (we refrained from controlling for education, as descriptive

12 statistics revealed no group differences for this potential covariate).

13 In addition, we associated the domain scores with CSF biomarker values in

14 the complete sample, as well as in the two subsamples (Pearson

15 correlations). This analysis was conducted in a reduced sample of $n=180$

16 participants $(\mathrm{n}=76 \mathrm{HC}, \mathrm{n}=104$ SCD). Individuals with available CSF were

17 slightly younger $(M=69.5, S D=5.34)$ than those without $C S F$ data $(M=70.3$,

$18 \mathrm{SD}=5.78)$. However, this difference was not significant, nor did they differ in

19 terms of sex or education years. CSF availability (36.4\% in $\mathrm{HC}, 43 \%$ in SCD)

20 did not significantly differ between the groups.

21 Finally, as we observed a significantly higher proportion of APOE4 carriers in 22 the SCD compared to the $\mathrm{HC}$ group (see table 1), we reran the analyses of

23 group differences in cognitive performance with APOE status as an additional

24 covariate. The same was done for the analyses of association of CSF

25 markers with cognitive performance (multiple regressions with APOE status 
1 and the respective biomarker as predictors). APOE genotype information was

2 available in $86 \%$ of the $\mathrm{HC}$ and SCD cases. Availability of APOE information

3 did not differ between groups and no differences in age, sex or education was

4 found between those with vs. without genetic data.

\section{Data availability}

6 Anonymized data generated and analyzed in the current study will be made

7 available upon request from any qualified investigator for purposes of

8 replicating procedures and results.

\section{Results}

10 Descriptive statistics of demographical, clinical, APOE4 and

11 neuropsychological data for the two subgroups are shown in table 1.

12 Group differences in global and domain-specific cognitive performance

13 (figure 1)

14 Age- and sex-adjusted comparisons of cognitive domain scores (ANCOVA)

15 revealed significantly lower performance of similar magnitudes in MEM,

16 EXEC, LANG and the global performance scores (Cohen's $d=0.2-0.5$,

$17 \mathrm{p}<0.05)$ in the SCD compared to HC group. No significant group differences

18 were found for WM and VIS. Addition of APOE status as a covariate did not

19 alter these results and no main effects of APOE status were observed.

20 Association of cognitive performance with self-experienced and informant-

21 rated cognitive decline (table 2)

22 In the complete sample, we observed significant associations between worse

23 objective cognitive performance and more domains with self-experienced and 
1 informant-rated cognitive decline. These associations were stronger for the

2 informant report. The association between the number of domains with

3 subjectively experienced decline and objective cognitive performance was

4 less pronounced and not significant within the two subgroups. However, for

5 the SCD group, we observed consistent associations of stronger (i.e., more

6 domains) informant-reported cognitive decline and worse cognitive

7 performance.

8 Association of cognitive performance with AD biomarkers (table 3)

9 In the complete sample, we observed significant associations of small to

10 moderate effect size for MEM, LANG and EXEC with biomarkers of amyloid

11 pathology, neurodegeneration (total Tau), and the CSF-Aß42/p-Tau181 ratio.

12 Correlations to pTau181 alone were weaker and reached significance only for

13 MEM and EXEC. WM and VIS were not associated with any of the AD

14 biomarkers. Subgroup analysis showed that consistent associations between

15 cognitive performance and biomarkers of amyloid as well as Tau pathology

16 were present in the SCD but not in the HC group. Again, these were strongest

17 for MEM, followed by EXEC and LANG with a smaller association with WM.

18 Addition of APOE4 as a covariate did not change this pattern of results and no

19 main effects of APOE status were observed.

\section{Discussion}

21 The present study adds important novel evidence to a growing body of

22 literature characterizing memory clinic patients with SCD as an at risk group

23 for preclinical AD. Several studies have already demonstrated that individuals

24 with SCD, particularly when seeking help at a memory clinic, are of increased 
1 risk of clinical progression ${ }^{4}$ and show increased risk of having abnormal

2 biomarkers consistent with preclinical AD (e.g. ${ }^{25-27}$ ). However,

3 neuropsychological performance in memory clinic SCD patients compared to

4 healthy controls has not been extensively studied so far, possibly due to the

5 assumption that SCD by default implies "cognitive normality". The few studies

6 reporting on differences in cognitive scores between memory clinic SCD

7 patients and healthy controls either had to rely on rather small samples

8 (e.g. $\left.{ }^{26}\right)$ or only reported on differences in a single memory test ${ }^{27}$.To our

9 knowledge, the present study is the first to demonstrate a profile of subtle

10 neuropsychological deficits and their relation to CSF biomarkers in a

11 considerably large sample of memory clinic SCD patients in comparison to

12 healthy control subjects. Certain strength of this study is that we measured

13 cognitive performance with an extensive neuropsychological battery allowing

14 us to employ state-of-the-art CFA methods to derive domain-specific cognitive

15 performance scores of high psychometric quality. We confirmed a 5 -factor

16 structure with very good model fit and comparability to similar cohorts, such

17 as the ADNI and WRAP study cohorts, which is important in terms of

18 replication and integrative data analysis ${ }^{28}$. The factors in DELCODE show a

19 somewhat higher intercorrelation compared to the WRAP cohort (see figure e-

20 1). However, the same is true for the ADNI cohort, which, similar to

21 DELCODE, has a higher mean age (and variance) and based their CFA

22 model on a mixed population of cognitively normal and impaired $(\mathrm{MCl}$, mild

23 AD dementia) individuals. Both aspects can influence the factor structure of

24 neuropsychological test batteries ${ }^{29}$. However, each factor still yielded

25 approximately $50 \%$ unique variance, which justifies the modeling of domain-

26 specific scores of cognitive performance. This may enhance the potential to 
1 detect differential deficits across a wide range of at-risk individuals. Such

2 domain-specific deficits (or decline) may then be differentially associated with

3 genetic and other risk factors or biomarkers of neurodegenerative disease ${ }^{30}$.

4 There are several important findings from the recent study. First, we indeed

5 observed a significantly reduced overall cognitive performance (about -0.3

$6 \mathrm{SD}$ ) in SCD vs. HC. To put this in perspective, the MCl and AD-dementia

7 group of DELCODE have global performance scores of -2.37 and -5.24 ,

8 respectively, when expressed as z-scores with the DELCODE HC group

9 performance as reference. Thus, the performance deficits in SCD are indeed

10 subtle and well within the range of cognitive normality. We found that deficits

11 were strongest in the memory domain, for which a performance deficit of

12 similar magnitude (Cohen's $\mathrm{d} \approx 0.5$, based on ADAS-Cog delayed recall) was

13 recently reported in a memory clinic SCD sample from the BioFINDER study

$14{ }^{27}$. We further observed significant deficits in executive functions and

15 language abilities. These findings are in line with previous findings on the

16 earliest AD-related cognitive decline and subtle impairment in the stage of

17 cognitive normality ${ }^{31-36}$.

18 We observed a higher proportion of APOE4 carriers compared to HC

19 suggesting that the SCD patient group is enriched for genetic risk (and, thus,

20 very likely also for familial history) of AD. However, results from our

21 supplementary analyses with additional covariate control for APOE status

22 suggested that the subtle deficits in SCD vs. HC and their association to CSF

23 biomarker pathology could not be directly attributed to an APOE4 effect.

24 Nevertheless, familial history of AD may be a driving factor for developing

25 worries and, consequently, help-seeking behavior in elderly individuals who 
1 experience subjective cognitive decline. It is, thus, of high interest to further

2 investigate the association of familial history as a clinical feature with

3 cognition and biomarker abnormalities in our SCD group. Likewise it is of

4 interest whether presence of SCD (or specific features thereof) in cognitively

5 normal elderly with a family history of $A D$ may be associated with $A D$

6 biomarkers, as has recently been shown in a study using data from the

7 PREVENT-AD cohort, albeit relying on a SCD group classification based on a

8 single SCD question ${ }^{37}$. We will conduct further analyses to address the

9 aforementioned questions once data on familial history of AD in the SCD and

$10 \mathrm{HC}$ group, as well as a sufficient sample size of the AD relatives group will be

11 available with the complete DELCODE baseline data set.

12 Second, despite being subtle, the consistent relation to AD biomarkers

13 supports the validity of these earliest deficits as being related to AD pathology

14 in the SCD group. Here, we observed consistent associations with CSF AD

15 biomarkers of amyloid and Tau pathology in exactly those cognitive domains

16 that showed a deficit in comparison to HC (MEM, LANG, EXEC). In contrast,

17 covariance between worse cognitive performance and $A D$ biomarkers was all

18 but absent in HC. With regard to the early identification of preclinical $A D$,

19 refined assessment of objective cognitive deficits in combination with

20 assessment of subjective experience of cognitive decline may, thus, prove to

21 be the most valuable approach, i.e., exceeding a strategy relying on only one

22 of these clinical phenotypes.

23 This distinctive pattern of results has highly relevant implications for the

24 conceptualization of future clinical trials for disease modifying interventions in

25 the pre-MCl stages of $A D$ and, more specifically, for consideration of SCD 
1 patients as a target population for these interventions. The general implication

2 of our results is that cognitive function, if measured by a combination of

3 sensitive neuropsychological tests, can be considered a suitable and

4 adequate outcome measure to test "disease modification" in preclinical AD

5 stages, supporting its recent FDA approval as a key outcome measure

6 irrespective of functional measures ${ }^{38}$. In addition, the stronger correlation

7 between Aß42/pTau181 and MEM, LANG, EXEC supports a specific

8 weighting of cognitive outcome measures towards these domains rather than

9 using a global cognitive performance score. Of note, this is already realized in

10 some composite scores developed to track cognitive decline in preclinical AD,

11 such as the $\mathrm{PACC}^{9}$. With regard to SCD in particular, our results support this

12 clinical stage as the transitional "sweet spot" between $\mathrm{HC}$ and $\mathrm{MCl}$, where $\mathrm{AD}$

13 pathology (of both amyloid and Tau) initially translates into detectable

14 cognitive dysfunction. This is particularly striking in consideration of the

15 relatively similar amounts of $A D$ pathology in both $\mathrm{HC}$ and SCD at the group

16 level (table 1). This finding is also consistent with previous nonclinical studies

17 showing that more severe subjective cognitive decline in healthy elderly

18 patients with the presence of amyloid pathology was associated with steeper

19 objective cognitive decline ${ }^{39}$ and a higher risk of clinical progression ${ }^{40}$.

20 Furthermore, a very recent study by Timmers et al. based on data from the

21 Amsterdam SCIENCE project ${ }^{34}$ - a memory clinic SCD patient study with

22 high comparability to DELCODE - reported cognitive decline in the presence

23 of higher PET amyloid load in tests of memory, attention/executive function

24 and language. Combined with these longitudinal results, the results from our

25 study that contrasted SCD patients with a healthy control group are

26 particularly promising with regard to clinical trials: they suggest that at the 
1 SCD stage, potential disease-modifying effects will translate into the relatively

2 strongest, and thus most likely detectable, effects on a cognitive outcome,

3 especially if optimally tailored with regard to domain specificity. Although more

4 longitudinal data are needed to further confirm this assumption, our results, in

5 line with that of Timmers et al. ${ }^{34}$, provide important empirical support for the

6 inclusion of SCD as an indicator of "stage 2" in the latest NIA-AA research

7 framework's numerical clinical staging system of individuals in the Alzheimer's

8 continuum ${ }^{23}$.

9 Last, we found only weak and inconsistent associations between the cognitive

10 domain scores and self-reported levels of cognitive complaint. This finding is

11 in line with previous studies based on questionnaires for self- vs. informant

12 rated everyday cognitive function (such as the $E \operatorname{Cog}{ }^{41}$ ). It emphasizes the

13 common observation that SCD, reflecting the notion of a subtle decline from a

14 previous level of cognitive function, is predictive of future AD dementia and

15 AD biomarkers irrespective of an association with a single, concomitant

16 measurement of objective cognitive performance ${ }^{5}$. On the other hand, we

17 here found informant reports of cognitive decline consistently associated with

18 worse objective cognitive performance. Specifically, in the SCD group, the

19 latter was in turn associated with AD pathology. This supports "informant

20 corroboration of SCD" as one of the "SCD-plus" features, which, pending

21 further empirical evidence, were proposed specifically to increase the

22 likelihood of underlying AD pathology ${ }^{1,2}$. In line with this, Miebach and

23 colleagues ${ }^{21}$ indeed reported an association of informant confirmation of self-

24 reported cognitive decline with AD biomarker pathology in the DELCODE

25 cognitively normal participants. Given the aforementioned findings, examining

26 the relative contribution of subtle objective deficits, self- and informant 
1 reported decline in the prediction of preclinical $A D$ is of high interest. While

2 this is beyond the scope of the present study, we will address these questions

3 in future analyses.

4 This study is not without limitations. As mentioned, longitudinal data will be

5 needed to more thoroughly test some of the aforementioned assumptions

6 concerning the benefits of the SCD concept and domain-specific cognitive

7 outcomes in clinical trial conceptualization. However, as DELCODE is a

8 relatively new study, we had to rely on cross-sectional baseline data for the

9 present analysis. Once follow-up data from DELCODE are available, we will

10 also analyze the sensitivity of our derived cognitive domain scores to detect

11 AD-related cognitive decline, comparing them with other composites (like the

12 PACC). It will then also be of interest to test whether changes in biomarkers

13 are associated differentially with decline in different cognitive domains. As

14 already mentioned above, the yet relatively small number of $A D$ relatives

15 ( $n=44$ of which $n=22$ had available CSF) led us to postpone inclusion of

16 comparative analyses with the SCD group in the present study. We will

17 address the issue of parental history of $A D$ in future analyses. Finally, it

18 should be emphasized that the SCD group in DELCODE is recruited from

19 help-seeking individuals attending a memory clinic for diagnostic work-up.

20 While this is first and foremost a clear strength rather than a limitation of the

21 present study, it still implies that results should not be generalized to

22 individuals with SCD in nonclinical, i.e., general population-based settings.

23 There is growing evidence supporting the greater relevance of SCD with

24 regard to $A D$ risk in the clinical, help-seeking setting rather than in the general

25 elderly population ${ }^{4,26}$, and harmonization of SCD research criteria will need to 26 take this into account ${ }^{2,42}$. 
1 In summary, we conclude that SCD patients presenting to a memory clinic

2 have, on average, minor neuropsychological deficits. These earliest deficits

3 seem to be domain specific, detectable with sensitive assessment and

4 appropriate psychometric techniques, and associated with biomarkers of $A D$

5 pathology. Thus, cognitive performance in patients with SCD will likely be a

6 sensitive outcome measure in studies of risk factors and in interventional

7 trials, and may also predict clinical progression. Albeit their measurement in

8 individual patients remains a challenge, minor cognitive deficits should also be

9 considered in the ongoing efforts to refine the conceptualization of SCD in the

10 context of preclinical $A D$ research. 


\section{Appendix 1 - Author's contribution to the manuscript}

\begin{tabular}{|c|c|c|c|}
\hline Name & Location & Role & Contribution \\
\hline Steffen Wolfsgruber, PhD & $\begin{array}{l}\text { German Center for } \\
\text { Neurodegenerative } \\
\text { Diseases (DZNE) } \\
\text { Bonn, Germany }\end{array}$ & Author & $\begin{array}{l}\text { Conceptualization and design of the } \\
\text { study; Statistical Analysis; } \\
\text { Interpretation of data; Drafting } \\
\text { and/or revision of manuscript for } \\
\text { important intellectual content }\end{array}$ \\
\hline Luca Kleineidam, M.Sc. & $\begin{array}{l}\text { DZNE Bonn, } \\
\text { Germany }\end{array}$ & Author & $\begin{array}{l}\text { Conceptualization and design of the } \\
\text { study; Statistical Analysis; } \\
\text { Interpretation of data; Drafting } \\
\text { and/or revision of manuscript for } \\
\text { important intellectual content }\end{array}$ \\
\hline Jannis Guski, B.Sc. & $\begin{array}{l}\text { DZNE Bonn, } \\
\text { Germany }\end{array}$ & Author & $\begin{array}{l}\text { Statistical Analysis; Interpretation of } \\
\text { data; Drafting and/or revision of } \\
\text { manuscript for important intellectual } \\
\text { content }\end{array}$ \\
\hline Alexandra Polcher M.Sc. & $\begin{array}{l}\text { DZNE Bonn, } \\
\text { Germany }\end{array}$ & Author & $\begin{array}{l}\text { Drafting and/or revision of } \\
\text { manuscript for important intellectual } \\
\text { content }\end{array}$ \\
\hline Ingo Frommann, Dipl.-Psych. & $\begin{array}{l}\text { DZNE Bonn, } \\
\text { Germany }\end{array}$ & Author & $\begin{array}{l}\text { Drafting and/or revision of } \\
\text { manuscript for important intellectual } \\
\text { content }\end{array}$ \\
\hline Sandra Roeske, PhD & $\begin{array}{l}\text { DZNE Bonn, } \\
\text { Germany }\end{array}$ & Author & $\begin{array}{l}\text { Drafting and/or revision of } \\
\text { manuscript for important intellectual } \\
\text { content }\end{array}$ \\
\hline Eike Jakob Spruth, MD & $\begin{array}{l}\text { DZNE Berlin, } \\
\text { Germany }\end{array}$ & Author & $\begin{array}{l}\text { Drafting and/or revision of } \\
\text { manuscript for important intellectual } \\
\text { content }\end{array}$ \\
\hline Christiana Franke, MD & $\begin{array}{l}\text { DZNE Berlin, } \\
\text { Germany }\end{array}$ & Author & $\begin{array}{l}\text { Drafting and/or revision of } \\
\text { manuscript for important intellectual } \\
\text { content }\end{array}$ \\
\hline Josef Priller, MD & $\begin{array}{l}\text { DZNE Berlin, } \\
\text { Germany }\end{array}$ & Author & $\begin{array}{l}\text { Drafting and/or revision of } \\
\text { manuscript for important intellectual } \\
\text { content }\end{array}$ \\
\hline Ingo Kilimann, MD & $\begin{array}{l}\text { DZNE Rostock, } \\
\text { Germany }\end{array}$ & Author & $\begin{array}{l}\text { Drafting and/or revision of } \\
\text { manuscript for important intellectual } \\
\text { content }\end{array}$ \\
\hline Stefan Teipel, MD & $\begin{array}{l}\text { DZNE Rostock, } \\
\text { Germany }\end{array}$ & Author & $\begin{array}{l}\text { Drafting and/or revision of } \\
\text { manuscript for important intellectual } \\
\text { content }\end{array}$ \\
\hline Katharina Buerger, MD & $\begin{array}{l}\text { DZNE Munich, } \\
\text { Germany }\end{array}$ & Author & $\begin{array}{l}\text { Drafting and/or revision of } \\
\text { manuscript for important intellectual } \\
\text { content }\end{array}$ \\
\hline Daniel Janowitz & $\begin{array}{l}\text { DZNE Munich, } \\
\text { Germany }\end{array}$ & Author & $\begin{array}{l}\text { Drafting and/or revision of } \\
\text { manuscript for important intellectual } \\
\text { content }\end{array}$ \\
\hline
\end{tabular}




\begin{tabular}{|c|c|c|c|}
\hline Theresa Stapf & $\begin{array}{l}\text { DZNE Munich, } \\
\text { Germany }\end{array}$ & Author & $\begin{array}{l}\text { Drafting and/or revision of } \\
\text { manuscript for important intellectual } \\
\text { content }\end{array}$ \\
\hline Christoph Laske, MD & $\begin{array}{l}\text { DZNE Tübingen, } \\
\text { Germany }\end{array}$ & Author & $\begin{array}{l}\text { Drafting and/or revision of } \\
\text { manuscript for important intellectual } \\
\text { content }\end{array}$ \\
\hline Martina Buchmann, MD & $\begin{array}{l}\text { DZNE Tübingen, } \\
\text { Germany }\end{array}$ & Author & $\begin{array}{l}\text { Drafting and/or revision of } \\
\text { manuscript for important intellectual } \\
\text { content }\end{array}$ \\
\hline Oliver Peters, MD & $\begin{array}{l}\text { DZNE Berlin, } \\
\text { Germany }\end{array}$ & Author & $\begin{array}{l}\text { Drafting and/or revision of } \\
\text { manuscript for important intellectual } \\
\text { content }\end{array}$ \\
\hline Felix Menne, Dipl.-Psych. & $\begin{array}{l}\text { DZNE Berlin, } \\
\text { Germany }\end{array}$ & Author & $\begin{array}{l}\text { Drafting and/or revision of } \\
\text { manuscript for important intellectual } \\
\text { content }\end{array}$ \\
\hline $\begin{array}{l}\text { Manuel Fuentes Casan, Dipl.- } \\
\text { Psych. }\end{array}$ & $\begin{array}{l}\text { DZNE Berlin, } \\
\text { Germany }\end{array}$ & Author & $\begin{array}{l}\text { Drafting and/or revision of } \\
\text { manuscript for important intellectual } \\
\text { content }\end{array}$ \\
\hline Jens Wiltfang, MD & $\begin{array}{l}\text { DZNE Göttingen, } \\
\text { Germany }\end{array}$ & Author & $\begin{array}{l}\text { Drafting and/or revision of } \\
\text { manuscript for important intellectual } \\
\text { content }\end{array}$ \\
\hline Claudia Bartels, PhD & $\begin{array}{l}\text { DZNE Göttingen, } \\
\text { Germany }\end{array}$ & Author & $\begin{array}{l}\text { Drafting and/or revision of } \\
\text { manuscript for important intellectual } \\
\text { content }\end{array}$ \\
\hline Emrah Düzel, MD & $\begin{array}{l}\text { DZNE Magdeburg, } \\
\text { Germany }\end{array}$ & Author & $\begin{array}{l}\text { Drafting and/or revision of } \\
\text { manuscript for important intellectual } \\
\text { content }\end{array}$ \\
\hline Coraline Metzger, MD & $\begin{array}{l}\text { DZNE Magdeburg, } \\
\text { Germany }\end{array}$ & Author & $\begin{array}{l}\text { Drafting and/or revision of } \\
\text { manuscript for important intellectual } \\
\text { content }\end{array}$ \\
\hline Wenzel Glanz, MD & $\begin{array}{l}\text { DZNE Magdeburg, } \\
\text { Germany }\end{array}$ & Author & $\begin{array}{l}\text { Drafting and/or revision of } \\
\text { manuscript for important intellectual } \\
\text { content }\end{array}$ \\
\hline Manuela Thelen, Dipl.-Biol. & $\begin{array}{l}\text { Medical Faculty } \\
\text { University of } \\
\text { Cologne, Germany }\end{array}$ & Author & $\begin{array}{l}\text { Drafting and/or revision of } \\
\text { manuscript for important intellectual } \\
\text { content }\end{array}$ \\
\hline Annika Spottke, MD & $\begin{array}{l}\text { DZNE Bonn, } \\
\text { Germany }\end{array}$ & Author & $\begin{array}{l}\text { Drafting and/or revision of } \\
\text { manuscript for important intellectual } \\
\text { content }\end{array}$ \\
\hline Alfredo Ramirez, MD & $\begin{array}{l}\text { Medical Faculty } \\
\text { University of } \\
\text { Cologne, Germany }\end{array}$ & Author & $\begin{array}{l}\text { Drafting and/or revision of } \\
\text { manuscript for important intellectual } \\
\text { content }\end{array}$ \\
\hline Barbara Kofler, MD & $\begin{array}{l}\text { DZNE Bonn, } \\
\text { Germany }\end{array}$ & Author & $\begin{array}{l}\text { Drafting and/or revision of } \\
\text { manuscript for important intellectual } \\
\text { content }\end{array}$ \\
\hline Klaus Fließbach, MD & $\begin{array}{l}\text { DZNE Bonn, } \\
\text { Germany }\end{array}$ & Author & $\begin{array}{l}\text { Drafting and/or revision of } \\
\text { manuscript for important intellectual }\end{array}$ \\
\hline
\end{tabular}


Wolfsgruber et al. 26

\begin{tabular}{|c|c|c|c|}
\hline & & & content \\
\hline Anja Schneider, MD & $\begin{array}{l}\text { DZNE Bonn, } \\
\text { Germany }\end{array}$ & Author & $\begin{array}{l}\text { Drafting and/or revision of } \\
\text { manuscript for important intellectual } \\
\text { content }\end{array}$ \\
\hline Michael Heneka, MD & $\begin{array}{l}\text { DZNE Bonn, } \\
\text { Germany }\end{array}$ & Author & $\begin{array}{l}\text { Drafting and/or revision of } \\
\text { manuscript for important intellectual } \\
\text { content }\end{array}$ \\
\hline Dix Meiberth, M.Sc. & $\begin{array}{l}\text { Medical Faculty } \\
\text { University of } \\
\text { Cologne, Germany }\end{array}$ & Author & $\begin{array}{l}\text { Drafting and/or revision of } \\
\text { manuscript for important intellectual } \\
\text { content }\end{array}$ \\
\hline Frank Jessen, MD & $\begin{array}{l}\text { Medical Faculty } \\
\text { University of } \\
\text { Cologne, Germany }\end{array}$ & Author & $\begin{array}{l}\text { Conceptualization and design of the } \\
\text { study; Interpretation of data; } \\
\text { Drafting and/or revision of } \\
\text { manuscript for important intellectual } \\
\text { content }\end{array}$ \\
\hline Michael Wagner, PhD & $\begin{array}{l}\text { DZNE Bonn, } \\
\text { Germany }\end{array}$ & Author & $\begin{array}{l}\text { Conceptualization and design of the } \\
\text { study; Interpretation of data; } \\
\text { Drafting and/or revision of } \\
\text { manuscript for important intellectual } \\
\text { content }\end{array}$ \\
\hline
\end{tabular}

\section{Appendix 2-Coinvestigators of the DELCODE study group}

\begin{tabular}{|c|c|c|c|c|}
\hline Surname & First Name & Location & Role & Contribution \\
\hline Hauser & Dietmar & $\begin{array}{l}\text { DZNE Berlin, } \\
\text { Germany }\end{array}$ & psychologist & $\begin{array}{l}\text { neuropsychologic } \\
\text { al testing at site }\end{array}$ \\
\hline Lindner & Katja & $\begin{array}{l}\text { DZNE Berlin, } \\
\text { Germany }\end{array}$ & study nurse & $\begin{array}{l}\text { study } \\
\text { administration, } \\
\text { blood sampling at } \\
\text { site }\end{array}$ \\
\hline Megges & Herlind & $\begin{array}{l}\text { DZNE Berlin, } \\
\text { Germany }\end{array}$ & psychologist & $\begin{array}{l}\text { neuropsychologic } \\
\text { al testing at site }\end{array}$ \\
\hline Amthauer & Holger & $\begin{array}{l}\text { Charité Berlin, } \\
\text { Germany }\end{array}$ & Imaging & $\begin{array}{l}\text { MRI acquisition } \\
\text { and processing at } \\
\text { site }\end{array}$ \\
\hline Kainz & Christian & $\begin{array}{l}\text { Center for } \\
\text { Cognitive } \\
\text { Neuroscience } \\
\text { Berlin (CCNB), } \\
\text { Department of } \\
\text { Education and } \\
\text { Psychology, } \\
\text { Freie Universität } \\
\text { Berlin, Germany }\end{array}$ & Imaging & $\begin{array}{l}\text { MRI acquisition } \\
\text { and processing at } \\
\text { site }\end{array}$ \\
\hline Ehrlich & Marie & $\begin{array}{l}\text { DZNE Berlin, } \\
\text { Germany }\end{array}$ & study physician & $\begin{array}{l}\text { medical } \\
\text { examinations at } \\
\text { site }\end{array}$ \\
\hline Altenstein & Slawek & $\begin{array}{l}\text { DZNE Berlin, } \\
\text { Germany }\end{array}$ & psychologist & $\begin{array}{l}\text { neuropsychologic } \\
\text { al testing at site }\end{array}$ \\
\hline Beuth & Markus & Charité Berlin & study physician & $\begin{array}{l}\text { medical } \\
\text { examinations at } \\
\text { site }\end{array}$ \\
\hline
\end{tabular}


Wolfsgruber et al. 27

\begin{tabular}{|c|c|c|c|c|}
\hline Langenfurth & Anika & Charité Berlin & study physician & $\begin{array}{l}\text { medical } \\
\text { examinations at } \\
\text { site }\end{array}$ \\
\hline Lohse & Andreas & Charité Berlin & neuropsychologist & $\begin{array}{l}\text { neuropsychologic } \\
\text { al testing at site }\end{array}$ \\
\hline Villar Munoz & Irene & DZNE Berlin & neuropsychologist & $\begin{array}{l}\text { neuropsychologic } \\
\text { al testing at site }\end{array}$ \\
\hline Konstantina & Kafali & Charité Berlin & study physician & $\begin{array}{l}\text { medical } \\
\text { examinations at } \\
\text { site }\end{array}$ \\
\hline Barkhoff & Miriam & $\begin{array}{l}\text { DZNE Bonn, } \\
\text { Germany }\end{array}$ & $\begin{array}{l}\text { student research } \\
\text { assistant }\end{array}$ & $\begin{array}{l}\text { neuropsychologic } \\
\text { al testing at site }\end{array}$ \\
\hline Boecker & Henning & $\begin{array}{l}\text { DZNE Bonn, } \\
\text { Germany }\end{array}$ & PI-Imaging & $\begin{array}{l}\text { PI for PET data } \\
\text { sub study in } \\
\text { DELCODE }\end{array}$ \\
\hline Daamen & Marcel & $\begin{array}{l}\text { DZNE Bonn, } \\
\text { Germany }\end{array}$ & QA-Imaging & $\begin{array}{l}\text { PET data } \\
\text { acquisition, } \\
\text { processing, } \\
\text { quality control at } \\
\text { site }\end{array}$ \\
\hline Faber & Jennifer & $\begin{array}{l}\text { DZNE Bonn, } \\
\text { Germany }\end{array}$ & study physician & $\begin{array}{l}\text { medical } \\
\text { examinations at } \\
\text { site }\end{array}$ \\
\hline Fließbach & Klaus & $\begin{array}{l}\text { DZNE Bonn, } \\
\text { Germany }\end{array}$ & study physician & $\begin{array}{l}\text { medical } \\
\text { examinations at } \\
\text { site }\end{array}$ \\
\hline Hennes & Guido & $\begin{array}{l}\text { DZNE Bonn, } \\
\text { Germany }\end{array}$ & study nurse & $\begin{array}{l}\text { study } \\
\text { administration, } \\
\text { blood sampling at } \\
\text { site }\end{array}$ \\
\hline Herrmann & Gabi & $\begin{array}{l}\text { DZNE Bonn, } \\
\text { Germany }\end{array}$ & research assistant & $\begin{array}{l}\text { neuropsychologic } \\
\text { al testing at site }\end{array}$ \\
\hline Kalbhen & Pascal & $\begin{array}{l}\text { DZNE Bonn, } \\
\text { Germany }\end{array}$ & study physician & $\begin{array}{l}\text { medical } \\
\text { examinations at } \\
\text { site }\end{array}$ \\
\hline Kobeleva & Xenia & $\begin{array}{l}\text { DZNE Bonn, } \\
\text { Germany }\end{array}$ & study physician & $\begin{array}{l}\text { medical } \\
\text { examinations at } \\
\text { site }\end{array}$ \\
\hline Miebach & Lisa & $\begin{array}{l}\text { DZNE Bonn, } \\
\text { Germany }\end{array}$ & psychologist & $\begin{array}{l}\text { DELCODE } \\
\text { scientist at site }\end{array}$ \\
\hline Müller & Anna & $\begin{array}{l}\text { DZNE Bonn, } \\
\text { Germany }\end{array}$ & study nurse & $\begin{array}{l}\text { study } \\
\text { administration, } \\
\text { blood sampling at } \\
\text { site }\end{array}$ \\
\hline Schneider & Christine & $\begin{array}{l}\text { DZNE Bonn, } \\
\text { Germany }\end{array}$ & study physician & $\begin{array}{l}\text { medical } \\
\text { examinations at } \\
\text { site }\end{array}$ \\
\hline Voigt & Ina & $\begin{array}{l}\text { DZNE Bonn, } \\
\text { Germany }\end{array}$ & study physician & $\begin{array}{l}\text { medical } \\
\text { examinations at } \\
\text { site }\end{array}$ \\
\hline Westerteicher & Christine & $\begin{array}{l}\text { DZNE Bonn, } \\
\text { Germany }\end{array}$ & study physician & $\begin{array}{l}\text { medical } \\
\text { examinations at } \\
\text { site }\end{array}$ \\
\hline Widmann & Catherine & $\begin{array}{l}\text { DZNE Bonn, } \\
\text { Germany }\end{array}$ & neuropsychologist & $\begin{array}{l}\text { neuropsychologic } \\
\text { al testing at site }\end{array}$ \\
\hline Yilmaz & Sagik & $\begin{array}{l}\text { DZNE Bonn, } \\
\text { Germany }\end{array}$ & study nurse & $\begin{array}{l}\text { study and MRI } \\
\text { administration at } \\
\text { site, }\end{array}$ \\
\hline Bartels & Claudia & $\begin{array}{l}\text { University } \\
\text { Medical Center }\end{array}$ & psychologist & $\begin{array}{l}\text { neuropsychologic } \\
\text { al testing at site }\end{array}$ \\
\hline
\end{tabular}


Wolfsgruber et al. 28

\begin{tabular}{|c|c|c|c|c|}
\hline & & Göttingen & & \\
\hline Hirschel & Sina & $\begin{array}{l}\text { University } \\
\text { Medical Center } \\
\text { Göttingen }\end{array}$ & psychologist & $\begin{array}{l}\text { neuropsychologic } \\
\text { al testing at site }\end{array}$ \\
\hline Nuhn & Sabine & $\begin{array}{l}\text { University } \\
\text { Medical Center } \\
\text { Göttingen }\end{array}$ & psychologist & $\begin{array}{l}\text { neuropsychologic } \\
\text { al testing at site }\end{array}$ \\
\hline Radenbach & Katrin & $\begin{array}{l}\text { University } \\
\text { Medical Center } \\
\text { Göttingen }\end{array}$ & study physician & $\begin{array}{l}\text { medical } \\
\text { examinations at } \\
\text { site }\end{array}$ \\
\hline Rausch & Lena & $\begin{array}{l}\text { University } \\
\text { Medical Center } \\
\text { Göttingen }\end{array}$ & psychologist & $\begin{array}{l}\text { neuropsychologic } \\
\text { al testing at site }\end{array}$ \\
\hline Sagebiel & Anne & $\begin{array}{l}\text { University } \\
\text { Medical Center } \\
\text { Göttingen }\end{array}$ & study physician & $\begin{array}{l}\text { medical } \\
\text { examinations at } \\
\text { site }\end{array}$ \\
\hline Vogelgsang & Jonathan & $\begin{array}{l}\text { University } \\
\text { Medical Center } \\
\text { Göttingen }\end{array}$ & study physician & $\begin{array}{l}\text { medical } \\
\text { examinations at } \\
\text { site }\end{array}$ \\
\hline Vukovich & Ruth & $\begin{array}{l}\text { University } \\
\text { Medical Center } \\
\text { Göttingen }\end{array}$ & study physician & $\begin{array}{l}\text { medical } \\
\text { examinations at } \\
\text { site }\end{array}$ \\
\hline Werner & Christine & $\begin{array}{l}\text { University } \\
\text { Medical Center } \\
\text { Göttingen }\end{array}$ & study physician & $\begin{array}{l}\text { medical } \\
\text { examinations at } \\
\text { site }\end{array}$ \\
\hline Zabel & Lioba & $\begin{array}{l}\text { University } \\
\text { Medical Center } \\
\text { Göttingen }\end{array}$ & study nurse & $\begin{array}{l}\text { study } \\
\text { administration, } \\
\text { blood sampling at } \\
\text { site }\end{array}$ \\
\hline Zech & Heike & $\begin{array}{l}\text { University } \\
\text { Medical Center } \\
\text { Göttingen }\end{array}$ & study nurse & $\begin{array}{l}\text { study } \\
\text { administration, } \\
\text { blood sampling at } \\
\text { site }\end{array}$ \\
\hline Witzenhausen & Janin & $\begin{array}{l}\text { University } \\
\text { Medical Center } \\
\text { Göttingen }\end{array}$ & study physician & $\begin{array}{l}\text { medical } \\
\text { examinations at } \\
\text { site }\end{array}$ \\
\hline Pfahlert & Ilona & $\begin{array}{l}\text { University } \\
\text { Medical Center } \\
\text { Göttingen }\end{array}$ & Imaging & $\begin{array}{l}\text { MRI acquisition } \\
\text { and processing at } \\
\text { site }\end{array}$ \\
\hline Bader & Abdelmajid & $\begin{array}{l}\text { University } \\
\text { Medical Center } \\
\text { Cologne, } \\
\text { Germany }\end{array}$ & Study nurse & $\begin{array}{l}\text { study } \\
\text { administration }\end{array}$ \\
\hline Engels & Tanja & $\begin{array}{l}\text { University } \\
\text { Medical Center } \\
\text { Cologne, } \\
\text { Germany }\end{array}$ & study nurse & $\begin{array}{l}\text { study } \\
\text { administration, } \\
\text { blood sampling at } \\
\text { site }\end{array}$ \\
\hline Escher & Claus & $\begin{array}{l}\text { University } \\
\text { Medical Center } \\
\text { Cologne, } \\
\text { Germany }\end{array}$ & study physician & $\begin{array}{l}\text { medical } \\
\text { examinations at } \\
\text { site }\end{array}$ \\
\hline Ghiasi & $\begin{array}{l}\text { Nasim } \\
\text { Roshan }\end{array}$ & $\begin{array}{l}\text { University } \\
\text { Medical Center } \\
\text { Cologne, } \\
\text { Germany }\end{array}$ & Study physician & $\begin{array}{l}\text { medical } \\
\text { examinations at } \\
\text { site }\end{array}$ \\
\hline Marquardt & Benjamin & $\begin{array}{l}\text { University } \\
\text { Medical Center } \\
\text { Cologne, } \\
\text { Germany }\end{array}$ & study nurse & $\begin{array}{l}\text { study } \\
\text { administration, } \\
\text { blood sampling at } \\
\text { site }\end{array}$ \\
\hline Rostamzadeh & Ayda & $\begin{array}{l}\text { University } \\
\text { Medical Center }\end{array}$ & study physician & $\begin{array}{l}\text { medical } \\
\text { examinations at }\end{array}$ \\
\hline
\end{tabular}


Wolfsgruber et al. 29

\begin{tabular}{|c|c|c|c|c|}
\hline & & $\begin{array}{l}\text { Cologne, } \\
\text { Germany }\end{array}$ & & site \\
\hline Sannemann & Lena & $\begin{array}{l}\text { University } \\
\text { Medical Center } \\
\text { Cologne, } \\
\text { Germany }\end{array}$ & psychologist & $\begin{array}{l}\text { neuropsychologic } \\
\text { al testing at site }\end{array}$ \\
\hline Schild & Ann-Katrin & $\begin{array}{l}\text { University } \\
\text { Medical Center } \\
\text { Cologne, } \\
\text { Germany }\end{array}$ & neuropsychologist & $\begin{array}{l}\text { neuropsychologic } \\
\text { al testing at site }\end{array}$ \\
\hline Sorgalla & Susanne & $\begin{array}{l}\text { University } \\
\text { Medical Center } \\
\text { Cologne, } \\
\text { Germany }\end{array}$ & Study physician & $\begin{array}{l}\text { medical } \\
\text { examinations at } \\
\text { site }\end{array}$ \\
\hline Tscheuschler & Maike & $\begin{array}{l}\text { University } \\
\text { Medical Center } \\
\text { Cologne, } \\
\text { Germany }\end{array}$ & study physician & $\begin{array}{l}\text { medical } \\
\text { examinations at } \\
\text { site }\end{array}$ \\
\hline Lützerath & Hannah & $\begin{array}{l}\text { University } \\
\text { Medical Center } \\
\text { Cologne, } \\
\text { Germany }\end{array}$ & study physician & $\begin{array}{l}\text { medical } \\
\text { examinations at } \\
\text { site }\end{array}$ \\
\hline Maier & Franziska & $\begin{array}{l}\text { University } \\
\text { Medical Center } \\
\text { Cologne, } \\
\text { Germany }\end{array}$ & study physician & $\begin{array}{l}\text { medical } \\
\text { examinations at } \\
\text { site }\end{array}$ \\
\hline Bittner & Daniel & $\begin{array}{l}\text { DZNE } \\
\text { Magdeburg, } \\
\text { Germany }\end{array}$ & study physician & $\begin{array}{l}\text { medical } \\
\text { examinations at } \\
\text { site }\end{array}$ \\
\hline Hartmann & Deike & $\begin{array}{l}\text { DZNE } \\
\text { Magdeburg, } \\
\text { Germany }\end{array}$ & study nurse & $\begin{array}{l}\text { study } \\
\text { administration, } \\
\text { blood sampling at } \\
\text { site }\end{array}$ \\
\hline Dobisch & Laura & $\begin{array}{l}\text { DZNE } \\
\text { Magdeburg, } \\
\text { Germany }\end{array}$ & QA-Imaging & $\begin{array}{l}\text { MRI acquisition, } \\
\text { quality } \\
\text { assessment }\end{array}$ \\
\hline Nestor & Peter & $\begin{array}{l}\text { Queensland } \\
\text { Brain Institute }\end{array}$ & $\begin{array}{l}\text { former Co-PI } \\
\text { Magdeburg site }\end{array}$ & various projects \\
\hline Schulze & Peter & $\begin{array}{l}\text { DZNE } \\
\text { Magdeburg, } \\
\text { Germany }\end{array}$ & Imaging & $\begin{array}{l}\text { MRI acquisition } \\
\text { and processing at } \\
\text { site }\end{array}$ \\
\hline Tempelmann & Claus & $\begin{array}{l}\text { DZNE } \\
\text { Magdeburg, } \\
\text { Germany }\end{array}$ & Imaging & $\begin{array}{l}\text { MRI acquisition } \\
\text { and processing at } \\
\text { site }\end{array}$ \\
\hline Berron & David & $\begin{array}{l}\text { DZNE } \\
\text { Magdeburg, } \\
\text { Germany }\end{array}$ & study scientist & $\begin{array}{l}\text { various } \\
\text { DELCODE } \\
\text { scientific projects } \\
\text { at site }\end{array}$ \\
\hline Betts & Matthew & $\begin{array}{l}\text { DZNE } \\
\text { Magdeburg, } \\
\text { Germany }\end{array}$ & study scientist & $\begin{array}{l}\text { various } \\
\text { DELCODE } \\
\text { scientific projects } \\
\text { at site }\end{array}$ \\
\hline Cardenas-Blanco & Arturo & $\begin{array}{l}\text { DZNE } \\
\text { Magdeburg, } \\
\text { Germany }\end{array}$ & $\begin{array}{l}\text { imaging / study } \\
\text { scientist }\end{array}$ & $\begin{array}{l}\text { MRI acquisition } \\
\text { and processing at } \\
\text { site }\end{array}$ \\
\hline Ziegler & Gabriel & $\begin{array}{l}\text { DZNE } \\
\text { Magdeburg, } \\
\text { Germany }\end{array}$ & study scientist & $\begin{array}{l}\text { various } \\
\text { DELCODE } \\
\text { scientific projects } \\
\text { at site }\end{array}$ \\
\hline Yakupov & Renat & DZNE & study scientist & various \\
\hline
\end{tabular}


Wolfsgruber et al. 30

\begin{tabular}{|c|c|c|c|c|}
\hline & & $\begin{array}{l}\text { Magdeburg, } \\
\text { Germany }\end{array}$ & & $\begin{array}{l}\text { DELCODE } \\
\text { scientific projects } \\
\text { at site }\end{array}$ \\
\hline Speck & Oliver & $\begin{array}{l}\text { DZNE } \\
\text { Magdeburg, } \\
\text { Germany }\end{array}$ & $\begin{array}{l}\text { neuroimaging, } \\
\text { study scientist }\end{array}$ & $\begin{array}{l}\text { MRI acquisition } \\
\text { and processing at } \\
\text { site }\end{array}$ \\
\hline Acosta-Cabonero & Julio & $\begin{array}{l}\text { DZNE } \\
\text { Magdeburg, } \\
\text { Germany }\end{array}$ & $\begin{array}{l}\text { neuroimaging, } \\
\text { study scientist }\end{array}$ & $\begin{array}{l}\text { MRI acquisition } \\
\text { and processing at } \\
\text { site }\end{array}$ \\
\hline Catak & Cihan & $\begin{array}{l}\text { DZNE Munich, } \\
\text { Germany }\end{array}$ & study physician & $\begin{array}{l}\text { medical } \\
\text { examinations at } \\
\text { site }\end{array}$ \\
\hline Dichgans & Martin & $\begin{array}{l}\text { DZNE Munich, } \\
\text { Germany }\end{array}$ & $\mathrm{PI}$ & $\begin{array}{l}\text { P.I. DELCODE } \\
\text { site No.2 in } \\
\text { Munich }\end{array}$ \\
\hline Dörr & Angelika & $\begin{array}{l}\text { DZNE Munich, } \\
\text { Germany }\end{array}$ & study nurse & $\begin{array}{l}\text { study } \\
\text { administration, } \\
\text { blood sampling at } \\
\text { site }\end{array}$ \\
\hline Ertl-Wagner & Birgit & $\begin{array}{l}\text { DZNE Munich, } \\
\text { Germany }\end{array}$ & Imaging & $\begin{array}{l}\text { MRI acquisition } \\
\text { and processing at } \\
\text { site }\end{array}$ \\
\hline Huber & Brigitte & $\begin{array}{l}\text { DZNE Munich, } \\
\text { Germany }\end{array}$ & study nurse & $\begin{array}{l}\text { study } \\
\text { administration, } \\
\text { blood sampling at } \\
\text { site }\end{array}$ \\
\hline Markov & Eva & $\begin{array}{l}\text { DZNE Munich, } \\
\text { Germany }\end{array}$ & study nurse & $\begin{array}{l}\text { study } \\
\text { administration, } \\
\text { blood sampling at } \\
\text { site }\end{array}$ \\
\hline Müller & Claudia & $\begin{array}{l}\text { DZNE Munich, } \\
\text { Germany }\end{array}$ & study physician & $\begin{array}{l}\text { medical } \\
\text { examinations at } \\
\text { site }\end{array}$ \\
\hline Rominger & Axel & $\begin{array}{l}\text { DZNE Munich, } \\
\text { Germany }\end{array}$ & Imaging & $\begin{array}{l}\text { MRI acquisition } \\
\text { and processing at } \\
\text { site }\end{array}$ \\
\hline Seegerer & Anna & $\begin{array}{l}\text { DZNE Munich, } \\
\text { Germany }\end{array}$ & psychologist & $\begin{array}{l}\text { neuropsychologic } \\
\text { al testing at site }\end{array}$ \\
\hline Stephan & Julia & $\begin{array}{l}\text { DZNE Munich, } \\
\text { Germany }\end{array}$ & psychologist & $\begin{array}{l}\text { neuropsychologic } \\
\text { al testing at site }\end{array}$ \\
\hline Zollver & Adelgunde & $\begin{array}{l}\text { DZNE Munich, } \\
\text { Germany }\end{array}$ & study nurse & $\begin{array}{l}\text { study } \\
\text { administration, } \\
\text { blood sampling at } \\
\text { site }\end{array}$ \\
\hline Brüggen & Katharina & $\begin{array}{l}\text { DZNE Rostock, } \\
\text { Germany }\end{array}$ & study physician & $\begin{array}{l}\text { medical } \\
\text { examinations at } \\
\text { site }\end{array}$ \\
\hline Dyrba & Martin & $\begin{array}{l}\text { DZNE Rostock, } \\
\text { Germany }\end{array}$ & study scientist & $\begin{array}{l}\text { various } \\
\text { DELCODE } \\
\text { scientific projects } \\
\text { at site }\end{array}$ \\
\hline Hufen & Antje & $\begin{array}{l}\text { DZNE Rostock, } \\
\text { Germany }\end{array}$ & lab assistant & $\begin{array}{l}\text { Blood sample } \\
\text { processing \& } \\
\text { shipping }\end{array}$ \\
\hline Korp & Christin & $\begin{array}{l}\text { DZNE Rostock, } \\
\text { Germany }\end{array}$ & Study nurse & $\begin{array}{l}\text { ethical application } \\
\text { for sub-projects }\end{array}$ \\
\hline Lau & Esther & $\begin{array}{l}\text { DZNE Rostock, } \\
\text { Germany }\end{array}$ & study nurse & $\begin{array}{l}\text { study } \\
\text { administration, } \\
\text { blood sampling at } \\
\text { site }\end{array}$ \\
\hline Pfaff & Henrike & DZNE Rostock, & study nurse & study \\
\hline
\end{tabular}


Wolfsgruber et al. 31

\begin{tabular}{|c|c|c|c|c|}
\hline & & Germany & & $\begin{array}{l}\text { administration, } \\
\text { blood sampling at } \\
\text { site }\end{array}$ \\
\hline Raum & Heike & $\begin{array}{l}\text { DZNE Rostock, } \\
\text { Germany }\end{array}$ & study nurse & $\begin{array}{l}\text { study } \\
\text { administration, } \\
\text { blood sampling at } \\
\text { site }\end{array}$ \\
\hline Sabik & Petr & $\begin{array}{l}\text { DZNE Rostock, } \\
\text { Germany }\end{array}$ & study nurse & $\begin{array}{l}\text { study } \\
\text { administration, } \\
\text { blood sampling at } \\
\text { site }\end{array}$ \\
\hline Sänger & Peter & $\begin{array}{l}\text { DZNE Rostock, } \\
\text { Germany }\end{array}$ & Imaging & $\begin{array}{l}\text { study } \\
\text { administration, } \\
\text { blood sampling at } \\
\text { site }\end{array}$ \\
\hline Schmidt & Monika & $\begin{array}{l}\text { DZNE Rostock, } \\
\text { Germany }\end{array}$ & study nurse & $\begin{array}{l}\text { study } \\
\text { administration, } \\
\text { blood sampling at } \\
\text { site }\end{array}$ \\
\hline Szagarus & Anna & $\begin{array}{l}\text { DZNE Rostock, } \\
\text { Germany }\end{array}$ & psychologist & $\begin{array}{l}\text { neuropsychologic } \\
\text { al testing at site }\end{array}$ \\
\hline Weschke & Sarah & $\begin{array}{l}\text { DZNE Rostock, } \\
\text { Germany }\end{array}$ & psychologist & $\begin{array}{l}\text { neuropsychologic } \\
\text { al testing at site }\end{array}$ \\
\hline Janecek-Meyer & Heike & $\begin{array}{l}\text { DZNE Rostock, } \\
\text { Germany }\end{array}$ & lab assistant & $\begin{array}{l}\text { Blood sample } \\
\text { processing \& } \\
\text { shipping }\end{array}$ \\
\hline Schulz & Heike & $\begin{array}{l}\text { DZNE Rostock, } \\
\text { Germany }\end{array}$ & study nurse & $\begin{array}{l}\text { study } \\
\text { administration, } \\
\text { blood sampling at } \\
\text { site }\end{array}$ \\
\hline Schwarzenboeck & & $\begin{array}{l}\text { DZNE Rostock, } \\
\text { Germany }\end{array}$ & Imaging & $\begin{array}{l}\text { MRI acquisition } \\
\text { and processing at } \\
\text { site }\end{array}$ \\
\hline Weber & Marc-Andre & $\begin{array}{l}\text { DZNE Rostock, } \\
\text { Germany }\end{array}$ & Imaging & $\begin{array}{l}\text { MRI acquisition } \\
\text { and processing at } \\
\text { site }\end{array}$ \\
\hline Buchmann & Martina & $\begin{array}{l}\text { DZNE Tübingen, } \\
\text { Germany }\end{array}$ & study physician & $\begin{array}{l}\text { medical } \\
\text { examinations at } \\
\text { site }\end{array}$ \\
\hline Hinderer & Petra & $\begin{array}{l}\text { DZNE Tübingen, } \\
\text { Germany }\end{array}$ & study nurse & $\begin{array}{l}\text { study } \\
\text { administration, } \\
\text { blood sampling at } \\
\text { site }\end{array}$ \\
\hline Munk & Matthias & DZNE Tübingen & study physician & $\begin{array}{l}\text { medical } \\
\text { examinations at } \\
\text { site }\end{array}$ \\
\hline Sanzenbacher & Carolin & DZNE Tübingen & psychologist & $\begin{array}{l}\text { neuropsychologic } \\
\text { al testing at site }\end{array}$ \\
\hline
\end{tabular}


Wolfsgruber et al. 32

\section{References}

1. Jessen $F$, Amariglio RE, van Boxtel M, et al. A conceptual framework for research on subjective cognitive decline in preclinical Alzheimer's disease. Alzheimer's \& dementia the journal of the Alzheimer's Association; 2014;10(6):844-852.

2. Molinuevo JL, Rabin LA, Amariglio R, et al. Implementation of subjective cognitive decline criteria in research studies. Alzheimer's \& dementia the journal of the Alzheimer's Association; 2017;13(3):296-311.

3. Mitchell AJ, Beaumont H, Ferguson D, Yadegarfar M, Stubbs B. Risk of dementia and mild cognitive impairment in older people with subjective memory complaints: meta-analysis. Acta Psychiatrica Scandinavica; $2014 ; 130(6): 439-451$.

4. Slot, Rosalinde E R, Sikkes, Sietske A M, Berkhof J, et al. Subjective cognitive decline and rates of incident Alzheimer's disease and nonAlzheimer's disease dementia. Alzheimer's \& dementia the journal of the Alzheimer's Association; 2019;15(3):465-476.

5. Rabin LA, Smart CM, Amariglio RE. Subjective Cognitive Decline in Preclinical Alzheimer's Disease. Annual review of clinical psychology; 2017;13:369-396.

6. Jessen F, Spottke A, Boecker H, et al. Design and first baseline data of the DZNE multicenter observational study on predementia Alzheimer's disease (DELCODE). Alzheimer's research \& therapy; 2018;10(1):15. 
7. Dowling NM, Hermann B, La Rue A, Sager MA. Latent structure and factorial invariance of a neuropsychological test battery for the study of preclinical Alzheimer's disease. Neuropsychology; 2010;24(6):742-756.

8. Park LQ, Gross AL, McLaren DG, et al. Confirmatory factor analysis of the ADNI Neuropsychological Battery. Brain imaging and behavior; 2012;6(4):528-539.

9. Donohue MC, Sperling RA, Salmon DP, et al. The preclinical Alzheimer cognitive composite: measuring amyloid-related decline. JAMA neurology; 2014;71(8):961-970.

10. Folstein MF, Folstein SE, McHugh PR. "Mini-mental state": a practical method for grading the cognitive state of patients for the clinician. Journal of psychiatric research; 1975;12(3):189-198.

11. Mohs RC, Knopman D, Petersen RC, et al. Development of cognitive instruments for use in clinical trials of antidementia drugs: additions to the Alzheimer's Disease Assessment Scale that broaden its scope. The Alzheimer's Disease Cooperative Study. Alzheimer disease and associated disorders; 1997;11 Suppl 2:S13-21.

12. Grober E, Ocepek-Welikson K, Teresi JA. The free and cued selective reminding test: evidence of psychometric adequacy. Psychology Science Quarterly; 2009;51(3):266-282.

13. Petermann F, Lepach AC. Wechsler Memory Scale-Fourth Edition (WMS-IV). Manual zur Durchführung und Auswertung. Deutsche Übersetzung und Adaptation der WMS-IV von David Wechsler: Pearson Assessment, Frankfurt/Main; 2012. 
14. Lezak MD. Neuropsychological assessment: Oxford University Press, USA; 2004.

15. Thalmann B, Monsch AU, Schneitter M, et al. The cerad neuropsychological assessment battery (Cerad-NAB)—A minimal data set as a common tool for German-speaking Europe. Neurobiology of Aging; 2000;21:30.

16. Smith A. Symbol digit modalities test (SDMT) manual (revised) Western Psychological Services. Los Angeles; 1982.

17. Reitan RM. Validity of the Trail Making Test as an indicator of organic brain damage. Perceptual and motor skills; 1958;8(3):271-276.

18. Rouleau I, Salmon DP, Butters N, Kennedy C, McGuire K. Quantitative and qualitative analyses of clock drawings in Alzheimer's and Huntington's disease. Brain and cognition; 1992;18(1):70-87.

19. Polcher A, Frommann I, Koppara A, Wolfsgruber S, Jessen F, Wagner M. Face-Name Associative Recognition Deficits in Subjective Cognitive Decline and Mild Cognitive Impairment. Journal of Alzheimer's disease JAD; 2017;56(3):1185-1196.

20. Van Dam, Nicholas T, Sano M, Mitsis EM, et al. Functional neural correlates of attentional deficits in amnestic mild cognitive impairment. PloS one; 2013;8(1):e54035.

21. Miebach L, Wolfsgruber S, Polcher A, et al. Which features of subjective cognitive decline are related to amyloid pathology? Findings from the DELCODE study. Alzheimer's research \& therapy; 2019;11(1):66. 
22. Lewczuk P, Kornhuber J, Toledo JB, et al. Validation of the Erlangen Score Algorithm for the Prediction of the Development of Dementia due to Alzheimer's Disease in Pre-Dementia Subjects. Journal of Alzheimer's disease JAD; 2016;49(3):887.

23. Jack CR, Bennett DA, Blennow K, et al. NIA-AA Research Framework: Toward a biological definition of Alzheimer's disease. Alzheimer's \& dementia the journal of the Alzheimer's Association; 2018;14(4):535-562.

24. Bjerke M, Engelborghs S. Cerebrospinal Fluid Biomarkers for Early and Differential Alzheimer's Disease Diagnosis. Journal of Alzheimer's disease JAD; 2018;62(3):1199-1209.

25. SNITZ BE, Lopez OL, McDade E, et al. Amyloid- $\beta$ Imaging in Older Adults Presenting to a Memory Clinic with Subjective Cognitive Decline: A Pilot Study. Journal of Alzheimer's disease JAD; 2015;48 Suppl 1:S151-9.

26. Perrotin A, La Joie R, de La Sayette, Vincent, et al. Subjective cognitive decline in cognitively normal elders from the community or from a memory clinic: Differential affective and imaging correlates. Alzheimer's \& dementia the journal of the Alzheimer's Association; 2017;13(5):550-560.

27. Mattsson N, Insel PS, Palmqvist S, et al. Increased amyloidogenic APP processing in APOE $\square$ 4-negative individuals with cerebral $\beta$-amyloidosis. Nature communications; 2016;7:10918.

28. Curran PJ, Hussong AM. Integrative data analysis: the simultaneous analysis of multiple data sets. Psychological methods; 2009;14(2):81-100. 
29. Delis DC, Jacobson M, Bondi MW, Hamilton JM, Salmon DP. The myth of testing construct validity using factor analysis or correlations with normal or mixed clinical populations: lessons from memory assessment. Journal of the International Neuropsychological Society JINS; 2003;9(6):936-946.

30. Crane PK, Trittschuh E, Mukherjee S, et al. Incidence of cognitively defined late-onset Alzheimer's dementia subgroups from a prospective cohort study. Alzheimer's \& Dementia; 2017;13(12):1307-1316.

31. Bäckman L, Jones S, Berger A, Laukka EJ, Small BJ. Cognitive impairment in preclinical Alzheimer's disease: a meta-analysis.

Neuropsychology; 2005;19(4):520.

32. Baker JE, Lim YY, Pietrzak RH, et al. Cognitive impairment and decline in cognitively normal older adults with high amyloid- $\beta$ : a meta-analysis. Alzheimer's \& dementia: Diagnosis, assessment \& disease monitoring; 2017;6:108-121.

33. Schneider AL, Senjem ML, Wu A, et al. Neural correlates of domainspecific cognitive decline. Neurology; 2019;92(10):e1051-e1063.

34. Timmers T, Ossenkoppele R, Verfaillie SCJ, et al. Amyloid PET and cognitive decline in cognitively normal individuals: the SCIENCe project. Neurobiology of Aging; 2019;79:50-58.

35. van Harten AC, Smits LL, Teunissen CE, et al. Preclinical AD predicts decline in memory and executive functions in subjective complaints. Neurology; 2013;81(16):1409. 
36. Verfaillie SCJ, Witteman J, Slot RER, et al. High amyloid burden is associated with fewer specific words during spontaneous speech in individuals with subjective cognitive decline. Neuropsychologia; 2019.

37. Verfaillie, Sander C J, Pichet Binette A, Vachon-Presseau E, et al. Subjective Cognitive Decline Is Associated With Altered Default Mode Network Connectivity in Individuals With a Family History of Alzheimer's Disease. Biological psychiatry. Cognitive neuroscience and neuroimaging; 2018;3(5):463-472.

38. U.S. Department of Health and Human Services Food and Drug Administration. Early Alzheimer's Disease: Developing Drugs for Treatment: Guidance for Industry; 2018.

39. Vogel JW, Doležalová MV, La Joie R, et al. Subjective cognitive decline and $\beta$-amyloid burden predict cognitive change in healthy elderly. Neurology; 2017;89(19):2002-2009.

40. Buckley RF, Maruff P, Ames D, et al. Subjective memory decline predicts greater rates of clinical progression in preclinical Alzheimer's disease. Alzheimer's \& Dementia; 2016;12(7):796-804.

41. Rueda AD, Lau KM, Saito N, et al. Self-rated and informant-rated everyday function in comparison to objective markers of Alzheimer's disease. Alzheimer's \& dementia the journal of the Alzheimer's Association; 2015;11(9):1080-1089.

42. Wolfsgruber S, Molinuevo JL, Wagner M, et al. Prevalence of abnormal Alzheimer's disease biomarkers in patients with subjective cognitive decline: 
Wolfsgruber et al. 38

cross-sectional comparison of three European memory clinic samples.

Alzheimer's research \& therapy; 2019;11(1):8. 
Table 1: Baseline characteristics of the whole study sample and subgroups

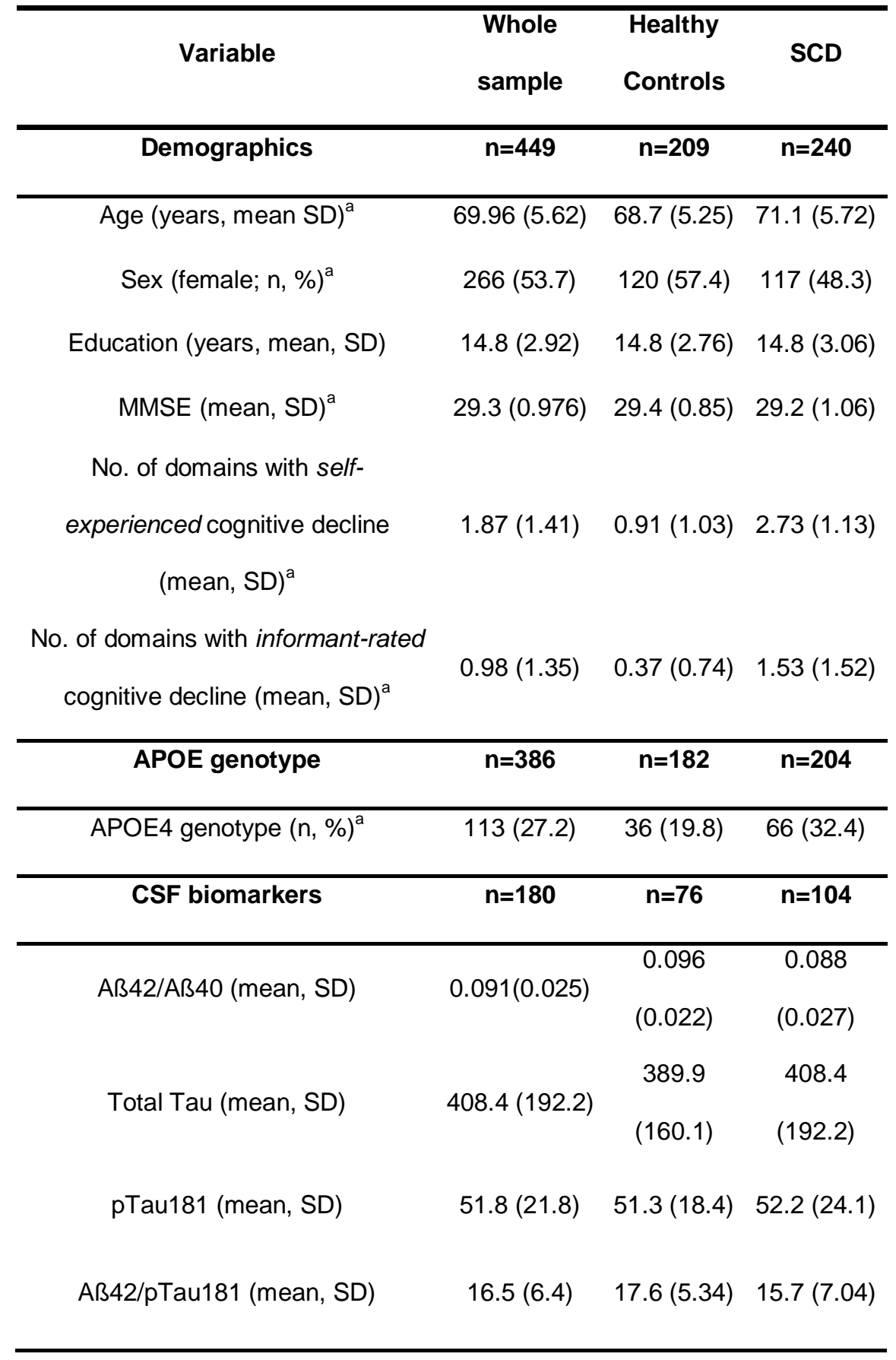

Note. ${ }^{a}$ group differences significantly different at the $\alpha \leq .05$ level, Chi ${ }^{2}$-Test for categorical variables and ANOVA for continuous variables. 
Table 2: Associations of cognitive domain scores with self- and informantrated number of domains with experienced cognitive decline.

\begin{tabular}{|c|c|c|}
\hline Whole cognitively normal sample ( $\mathrm{N}=449)$ & $\begin{array}{l}\text { No. of domains with } \\
\text { self-experienced } \\
\text { cognitive decline }\end{array}$ & $\begin{array}{c}\text { No. of domains with } \\
\text { informant-rated } \\
\text { cognitive decline }\end{array}$ \\
\hline MEM &,- 153 &,$- 304^{\prime \prime, a}$ \\
\hline LANG &,$- 107^{*}$ &,$- 239^{\prime \prime, a}$ \\
\hline EXEC &,$- 120^{\prime \prime}$ &,$- 221^{\cdots, a}$ \\
\hline WM &,- 066 &,$- 120^{*}$ \\
\hline VIS &,- 085 &,$- 106^{*}$ \\
\hline Global score &,$- 125^{* *}$ &,$- 235^{\mathrm{N}, \mathrm{a}}$ \\
\hline \multicolumn{3}{|l|}{ Healthy Controls $(\mathrm{N}=209)$} \\
\hline MEM & 041 &,- 132 \\
\hline LANG & ,039 &,- 091 \\
\hline EXEC & ,062 &,- 020 \\
\hline WM & ,056 & 047 \\
\hline VIS & 084 &,- 097 \\
\hline Global score & ,058 &,- 038 \\
\hline \multicolumn{3}{|l|}{ SCD patients ( $\mathrm{N}=240)$} \\
\hline MEM &, 003 & $-, 276, a$ \\
\hline LANG &,- 044 &,$- 241^{* \prime, a}$ \\
\hline EXEC &,- 088 &,$- 244^{\pi \times, a}$ \\
\hline WM &,- 073 &,$- 168^{*}$ \\
\hline VIS &,$- 133^{*}$ &,$- 174^{* *}$ \\
\hline Global score &,- 074 & $-, 252^{* * a}, a$ \\
\hline
\end{tabular}

Note: Values are Spearman-Rho correlation coefficients. ${ }^{* *} \mathrm{p}<0.01$ (two-tailed); ${ }^{*} \mathrm{p}<0.05$ (twotailed). ${ }^{a}$ significant difference in the correlation coefficient for self-experienced vs. informantreported decline. 
Table 3: Associations of cognitive domain scores with AD biomarkers.

\begin{tabular}{|c|c|c|c|c|}
\hline $\begin{array}{l}\text { Whole cognitively } \\
\text { normal sample ( } \mathrm{N}=180)\end{array}$ & CSF-AB42/40 & CSF-Tau & CSFpTau-181 & $\begin{array}{l}\text { CSF Aß42/ } \\
\text { pTau-181 }\end{array}$ \\
\hline MEM & .316 & -.287 & $-.270^{\circ}$ & .350 \\
\hline LANG & $.250^{* *}$ & $-.178^{*}$ & -.142 & $.247^{\prime \prime}$ \\
\hline EXEC & $.176^{*}$ & $-.171^{*}$ & $-.159^{*}$ & $.216^{\mathrm{N*}}$ \\
\hline WM & .089 & -.094 & -.098 & .104 \\
\hline VIS & .049 & -.094 & -.054 & .087 \\
\hline Global score & $.214^{\circ}$ & -.200 & -.175 & $.244^{\prime \prime}$ \\
\hline \multicolumn{5}{|l|}{ Healthy controls $(\mathrm{N}=76)$} \\
\hline MEM & .208 & -.080 & -.117 & .283 \\
\hline LANG & .158 & -.022 & .067 & .171 \\
\hline EXEC & .110 & -.024 & -.017 & .118 \\
\hline WM & .028 & .136 & .130 & -.017 \\
\hline VIS & .122 & -.081 & -.015 & .126 \\
\hline Global score & .157 & -.013 & .008 & .171 \\
\hline \multicolumn{5}{|l|}{ SCD patients $(\mathrm{N}=104)$} \\
\hline MEM & $.343^{\prime}$ & $-.389 ", a$ & $-.346 "$,a & $.355^{\prime \prime}$ \\
\hline LANG & $.279^{* *}$ & $-.262^{m * a}$ & $-.230^{-", a}$ & $.265^{* x}$ \\
\hline EXEC & .187 & $-.232^{x}$ & $-.220^{n} \cdot a$ & $.240^{\circ}$ \\
\hline WM & .114 & $-.195^{\star, a}$ & $-.195^{\star, a}$ & .154 \\
\hline VIS & .002 & -.102 & -.080 & .065 \\
\hline Global score & $.224^{*}$ & $-.282^{\mathrm{xx}, \mathrm{a}}$ & $-.256^{\mathrm{N}, \mathrm{a}}$ & $.259^{\pi *}$ \\
\hline
\end{tabular}

Note: Values are Pearson correlation coefficients. ${ }^{* *} \mathrm{p}<0.01$ (two-tailed); ${ }^{*} \mathrm{p}<0.05$ (two-tailed);

${ }^{a}$ significant difference in correlation coefficient compared to Healthy controls $(p<0.05$; onesided test according to the hypothesis that there is a closer association between worse cognitive performance and more pathological CSF-values in SCD compared to HC). 
Legend to Figure 1. Age- and sex-adjusted cognitive domain score performance across subgroups.

Note: Figure 1 shows age- and sex-adjusted performance differences between the groups of healthy controls and memory clinic patients with subjective cognitive decline (SCD) based on ANCOVA (see the Methods section for details). Values are expressed as zscores with the mean and standard deviation taken from the healthy control group. For visualization, the covariate age is set to the sample mean of 69.96 years. This value is higher than the mean age of the healthy control group, and age has a negative effect on performance. Hence, the mean performance of healthy controls in this depiction is also slightly below zero. * significant ( $p<0.05)$ difference in comparison to healthy control group. 


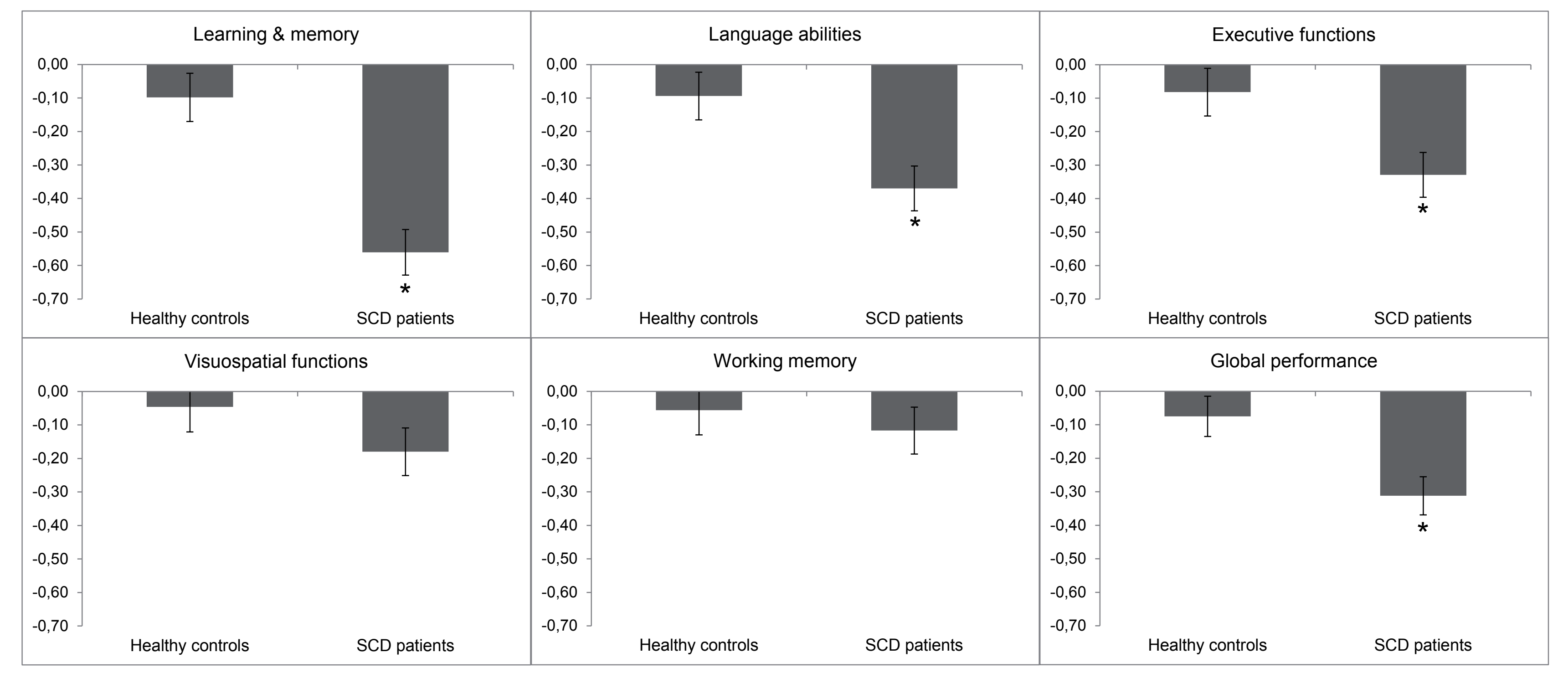

